\title{
GUIDELINES FOR SUSTAINABLE URBAN TRANSPORT IN SELECTED AREAS OF THE CITY OF TSHWANE, SOUTH AFRICA
}

\author{
BABRA DURI \& CINA VAN ZYL \\ Department of Entrepreneurship, Supply Chain, Transport, Tourism and Logistics Management, \\ University of South Africa, South Africa
}

\begin{abstract}
The purpose of this study was to investigate public attitudes towards sustainable urban transport in the City of Tshwane in order to develop guidelines for sustainable urban transport. The number of households owning private cars increased approximately from $22.9 \%$ in 2003 to $28.5 \%$ in 2013 . Geographical location is used for quota sampling so that all the seven regions in the Tshwane could be represented. The total sample size of the study is $(\mathrm{N}=418)$. Primary data is gathered by a structured questionnaire while the Likert scale method was employed to get public attitudes regarding sustainable urban transport. The City of Tshwane in South Africa had the largest increase in population using private cars between 2003 and 2013 of approximately $11.3 \%$, hence there is a need to shift from private cars to sustainable modes of transport. The findings of the research revealed that private cars are the most frequently used mode of transport in the City of Tshwane. The results also indicated that the majority of the residents of the City of Tshwane had a negative attitude towards sustainable transport modes and it was attributed to safety, reliability and convenience concerns. Finally, the paper provides recommendations on how the city planners need to implement transport initiatives that can improve the service quality and safety features of sustainable transport modes. The findings presented in this study provide useful insights to the city planners to secure sustainable urban transportation in the City of Tshwane.
\end{abstract}

Keywords: urban transport, sustainable transport, cycling, public transport, private car.

\section{INTRODUCTION}

Transport plays a critical role in any economy, influencing location of economic activity, the form and size of cities and the lifestyle. The frequent use of private cars in the city has significant negative impact on the environment and human life such as traffic congestion, air pollution and greenhouse gas (GHG) emissions among others [1], [2]. The transport sector is one of the major contributors to GHG emissions and overall, transport sector accounts for about $25 \%$ of global carbon dioxide $\left(\mathrm{CO}_{2}\right)$ emissions with land based transport accounting for $80 \%$ of the total [3]. Zheng and Hensher [4] concur that private cars contribute significant amount of GHG emissions in the city as well as significant consumption of fossil fuels. Luke [5] asserts if car usage is not managed properly, cities will likely face negative impacts of transport that are associated with traffic congestion that may affect economic growth and development.

Globally, urban transport is responsible for about three quarters of GHG produced from the transport sector [6], [7]. For the purpose of this study, the focus of the study is on urban transport, specifically on individual and passenger transport. In South Africa, the number of households owning private cars increased approximately from $22.9 \%$ in 2003 to $28.5 \%$ in 2013 [8]. The City of Tshwane in South Africa had the largest increase in population using private cars between 2003 and 2013 of approximately $11.3 \%$ hence there is a need to shift from private cars to sustainable modes of transport [8]. It is obvious that there is high growth in motorisation in the City of Tshwane and South Africa as a country. Therefore, these developments call for a paradigm towards sustainable urban transport. 
In the absence of proper sustainable urban transport polices or initiatives, it may lead to an increase in environmental, economic and social challenges. Successful implementation of sustainable transport policies is attributed by positive public attitudes [9]-[11]. Research done in Australia on attitudes to traffic revealed that even though the public was aware of the negative effects of car usage, their actions did not match their modal choice [12]. Negative attitudes towards sustainable urban transport may be changed through implementation of transport initiatives [9], [13]. Therefore transport initiatives to reduce car dependency in the cities and shift private car users to sustainable transport modes are crucial. Transport initiatives are measures that can encourage commuters to shift from private car use to sustainable alternative transport modes [14]-[18]. Successful implementation of transport initiatives among various cities around the world shows that behaviour of commuters can be changed through transport initiatives. The Department of Transport of South Africa developed Non-Motorised Transport (NMT) policy to be adopted by the South African cities in 2008 [19]. However, the implementation of NMT has been slow especially in the cities such as City of Tshwane and City of Johannesburg.

\section{RESEARCH METHOD}

This study was conducted within the City of Tshwane metropolitan region, South Africa. The City of Tshwane consists of seven administrative functional regions as shown in the Fig. 1. The City of Tshwane has a population of approximately 3,275,000 [20]. It is estimated that the City of Tshwane covers $6,368 \mathrm{~km}^{2}$ of Gauteng's $19,055 \mathrm{~km}^{2}$ making it one of the largest metropolitan municipality in South Africa in terms of coverage [21].

This empirical study used a survey to gather primary data. The population of this study consists of the residents from seven regions of the City of Tshwane. A sampling frame of selected residents of the City of Tshwane was not available for selecting the sampling

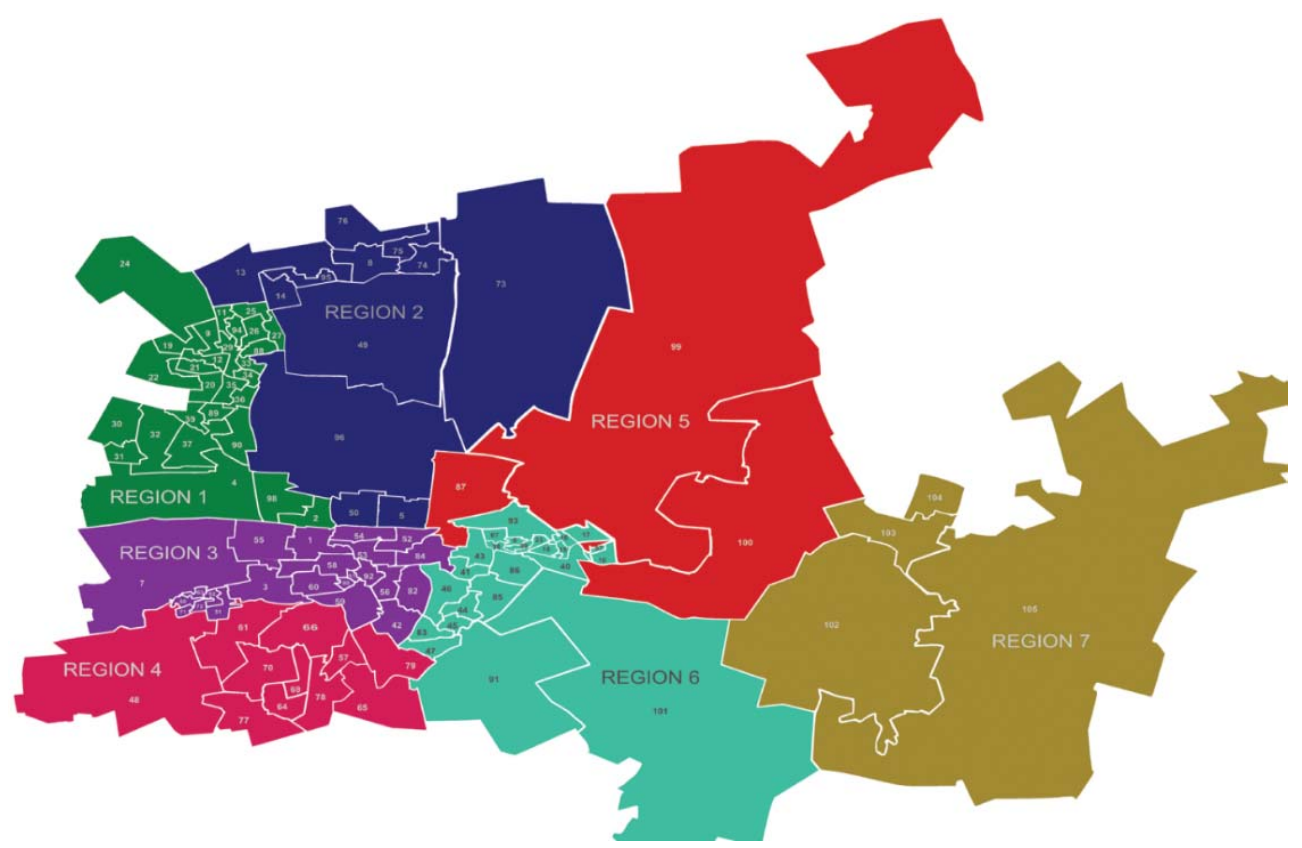

Figure 1: The study area: City of Tshwane regions. (Source: City of Tshwane, 2016.) 
elements; therefore, non-probability quota sampling was used to determine the sample for this study. Based on guidelines for determining sampling size, the recommended sample size is 418 [22], [23].

The questions related to the research objective of the study compiled in the questionnaire were based on previous research related to sustainable transport [9]-[12], [24]. Seventeen statements describing the public attitudes towards sustainable transport were provided and Likert scale used to rate level of agreement or disagreement with the statement on a scale of 1 (strongly disagree) to 5 (strongly agree). The questionnaire also contained twenty-three statements to determine the effectiveness of factors that might promote the use of sustainable transport. Likert scale was used to rate the effectiveness of these factors on a scale of 1 (not very effective) to 5 (very effective). Fellow researchers from University of South Africa, experts in the transport industry and other potential participants (general public) were asked to complete pilot questionnaire. Minor changes were applied based on their recommendations.

The data was collected during the month of August in the year 2017 by means of selfadministered questionnaire. The researcher collected data from busy areas of the City of Tshwane that were conducive to collect data such as city parks, sports venues and carwash premises. In order to reduce number of incomplete questionnaires, the researcher waited for the participants to fill in the questionnaires.

Once the fieldwork had been conducted and completed, data was coded, captured and cleaned. Analysis of results was done using Statistical Package for Social Sciences program (SPSS 17.0). Exploratory Factor analysis (EFA) was used to test validity of constructs followed by reliability test using Cronbach Alpha coefficient. The Principal Axis Factoring (PAF) extraction method was used to extract the factors. The results for validity and reliability tests are presented in the following section.

\section{RESULTS}

The residents of the City of Tshwane were asked to reflect on their agreement to sustainable transport. The main concern was finding out the attitudes of the residents of the City of Tshwane towards sustainable transport and the environment. The Kaiser-Meyer-Olkin (KMO) value was 0.799 , exceeding the recommended minimum value of 0.5 [23]. Bartlett's Test of Sphericity showed that P-value was below 0.05 indicating statistically significant structure that is viable to perform EFA on the items. Table 1 shows cumulative variance explained for by factors.

Factors in Table 1 are: Factor 1 - Traffic problem awareness; Factor 2 - Public transport; Factor 3 - Environmental awareness; Factor 4 - Private car; and Factor 5 - Cycling and

Table 1: Cumulative variance explained for by factors.

\begin{tabular}{|c|c|c|c|c|c|c|}
\hline & \multicolumn{5}{|c|}{ Total variance explained } \\
\hline & \multicolumn{3}{|c|}{ Initial eigenvalues } & \multicolumn{2}{c|}{ Extraction sums of squared loadings } \\
\hline Factor & Total & $\begin{array}{c}\text { \% of } \\
\text { variance }\end{array}$ & $\begin{array}{c}\text { Cumulative } \\
\%\end{array}$ & Total & $\begin{array}{c}\% \text { of } \\
\text { variance }\end{array}$ & $\begin{array}{c}\text { Cumulative } \\
\%\end{array}$ \\
\hline 1 & 4.404 & 25.906 & 25.906 & 3.954 & 23.260 & 23.260 \\
\hline 2 & 2.525 & 14.854 & 40.760 & 2.024 & 11.907 & 35.167 \\
\hline 3 & 1.396 & 8.213 & 48.973 & .907 & 5.334 & 40.501 \\
\hline 4 & 1.296 & 7.622 & 56.596 & .745 & 4.385 & 44.885 \\
\hline 5 & 1.121 & 6.596 & 63.192 & .614 & 3.614 & 48.499 \\
\hline
\end{tabular}


Table 2: Rotated factor pattern: Principle axis factoring.

\begin{tabular}{|c|c|c|}
\hline Items & Communalities & $\begin{array}{l}\text { Factor } \\
\text { loadings }\end{array}$ \\
\hline \multicolumn{3}{|l|}{ Factor 1 - Traffic problem awareness } \\
\hline Vehicles cause noise pollution & 0.677 & 0.836 \\
\hline Vehicle emissions are a threat to the environment & 0.616 & 0.709 \\
\hline $\begin{array}{l}\text { Vehicle related air pollution is dangerous to our } \\
\text { health }\end{array}$ & 0.578 & 0.672 \\
\hline $\begin{array}{l}\text { The more vehicles on the road, the more road } \\
\text { accidents resulting in injuries and deaths }\end{array}$ & 0.450 & 0.645 \\
\hline \multicolumn{3}{|l|}{ Factor 2 - Public transport } \\
\hline Public transport is convenient & 0.654 & 0.790 \\
\hline Public transport service is reliable for me & 0.694 & 0.721 \\
\hline There is good information about public transport & 0.448 & 0.674 \\
\hline Public transport is expensive for me & 0.201 & 0.413 \\
\hline \multicolumn{3}{|l|}{ Factor 3 - Environmental awareness } \\
\hline $\begin{array}{l}\text { From an environment point of view, it is important } \\
\text { that we reduce car use }\end{array}$ & 0.505 & 0.712 \\
\hline $\begin{array}{l}\text { Public transport is a more environmentally friendly } \\
\text { option than driving a car }\end{array}$ & 0.387 & 0.561 \\
\hline $\begin{array}{l}\text { Being environmentally responsible is important to me } \\
\text { Factor } 4 \text { - Private car }\end{array}$ & 0.341 & 0.390 \\
\hline A car is essential to satisfy my needs & 0.450 & 0.650 \\
\hline $\begin{array}{l}\text { I feel more comfortable in private cars than in other } \\
\text { transport }\end{array}$ & 0.435 & 0.600 \\
\hline \multicolumn{3}{|l|}{ Factor 5 - Cycling and walking } \\
\hline Walking and cycling can help me keep fit and healthy & 0.637 & 0.710 \\
\hline $\begin{array}{l}\text { If more people walked and cycled, this would have a } \\
\text { positive effect on our environment }\end{array}$ & 0.615 & 0.668 \\
\hline $\begin{array}{l}\text { Cycling and walking are more environmentally } \\
\text { friendly option than driving a car }\end{array}$ & 0.483 & 0.584 \\
\hline
\end{tabular}

walking. All the five factors revealed Eigenvalues exceeding 1, explaining 25.9\%, 14.9\%, $8.2 \%, 7.6 \%$, and $6.5 \%$ of the variance respectively. Table 1 shows that cumulative variance explained for by five factors was greater than $60 \%(63.19 \%)$. The scree plot however, indicated that only the first factors were meaningful. Therefore, the first five factors were retained for rotation.

In an effort to summarise the number of factors which impact public attitudes towards sustainable transport into unidimensional constructs, an EFA was performed. An EFA was applied to responses of the seventeen items of "Public attitudes towards sustainable transport" tested in the survey. The PAF extraction method was used to extract the factors in Table 2. Four items were found to load on the first factor, which was subsequently labeled "Traffic problem awareness". Four items loaded on the second factor, labeled "Public transport". Three items loaded on the third factor labeled "Environmental awareness". Two items loaded on the fourth factor labeled "Private car" and three items loaded on the fifth factor labeled "Cycling and walking". Low communalities value of 0.2 or lower were not included. Loadings of statement, "Cycling is a safer transport option for me" was lower than 
Table 3: Reliability statistics.

\begin{tabular}{|l|c|c|c|}
\hline Factor & Cronbach & Mean & Std dev \\
\hline $\begin{array}{l}\text { F1. Traffic problem } \\
\text { awareness }\end{array}$ & 0.833 & 4.2 & 0.87 \\
\hline F2. Public transport & 0.722 & 2.8 & 1.12 \\
\hline $\begin{array}{l}\text { F3. Environmental } \\
\text { awareness }\end{array}$ & 0.633 & 3.7 & 1.0 \\
\hline $\begin{array}{l}\text { F4. Private car } \\
\begin{array}{l}\text { F5. Cycling and } \\
\text { walking }\end{array}\end{array}$ & 0.601 & 4.0 & 0.96 \\
\hline
\end{tabular}

0.2 and it was not included. With this information, reliability test for "Public attitudes towards sustainable transport" construct were carried out and the results are shown in Table 3.

Reliability estimates were $0.833 ; 0.722 ; 0.633 ; 0.601$ and 0.777 for responses to "Traffic problem awareness"; "Public transport"; "Environmental awareness"; "Private car" and "Cycling and walking" respectively. Table 3 indicate that reliability estimates of internal consistency as measured by Cronbach's alpha, all exceeded 0.6 and the constructs were found to be reliable. The scale used was five-point Likert scale ( $1=$ strongly disagree to $5=$ strongly agree). Factors 1 and 5 had the highest mean score $(\mathrm{M}=4.2)$ indicating a stronger agreement to the factors while the lowest score $(\mathrm{M}=2.8)$ was found in Factor 2.

\section{DISCUSSION}

The study reveals that the majority of residents of the City of Tshwane are aware of the benefits of sustainable transport as well as traffic problems. The finding of the study is consistent with previous research which indicates that respondents agree that cycling and walking are good for human health and the environment [9], [25]. Even though the majority of residents of the City of Tshwane are aware of the benefits of sustainable transport the results show that they do not agree that there is a need to reduce car usage. This result is consistent with finding from previous research [12]. Therefore, comprehensive car restricting policies may be recommended to reduce car usage. Transport planners also need to think creative ways to change the notion.

The majority of the respondents were concerned about safety and comfort associated with cycling and private car. This finding is consistent with the previous research which indicates that cycling is not a safe mode of transport [9], [12], [25], [26]. It could be important for the City of Tshwane to improve cycling safety so as to promote cycling as a sustainable mode of transport. Cycling initiatives that improve safety of cycling tend to increase cycling among the public [27].

The majority of the respondents revealed that public transport does not offer good service to them. Some of the major concerns about public transport were convenience, reliability, and lack of information about public transport. It could be important for the City of Tshwane to improve the provision of public transport. Good national passenger system is recommended for increasing public transport ridership.

Based on the literature and results of this study a set of guidelines for sustainable urban transport have been developed for the City of Tshwane. Fig. 2 illustrates guidelines for sustainable urban transport for the City of Tshwane. 


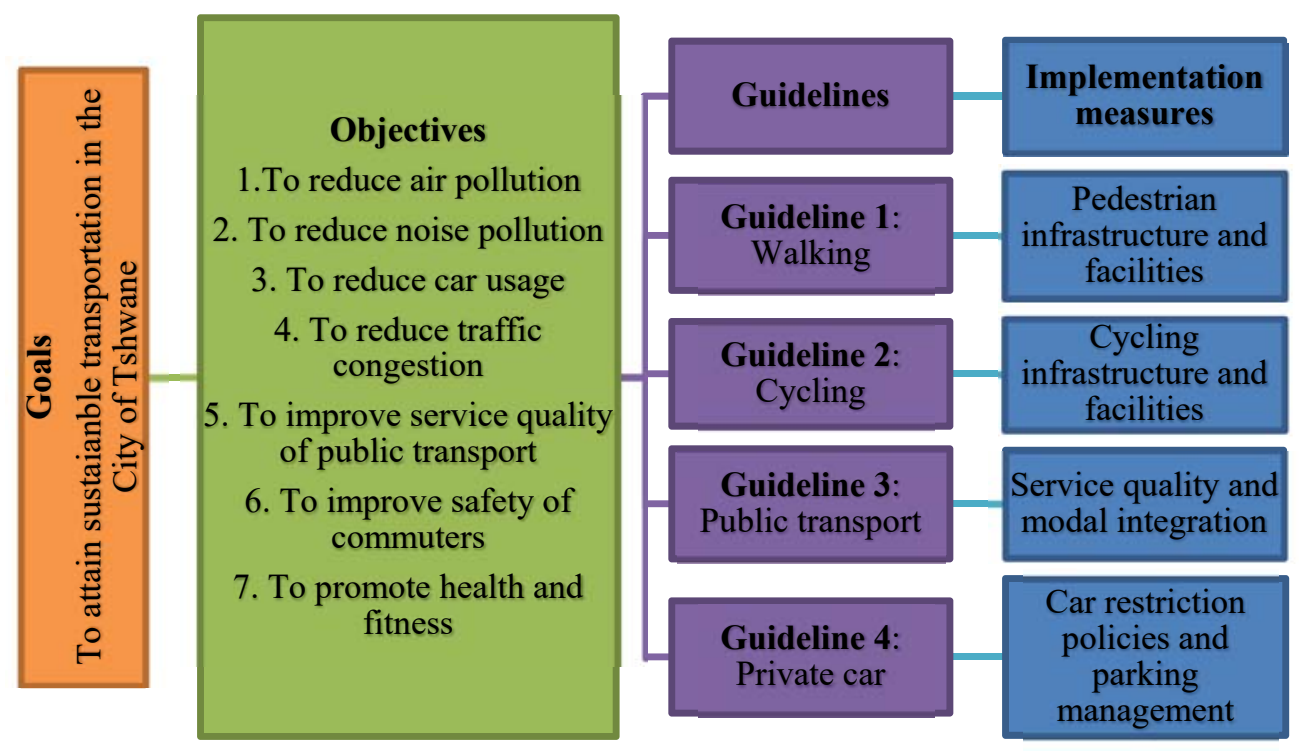

Figure 2: Guidelines for sustainable urban transport. (Source: Own synthesis.)

To attain sustainable urban transport in the City of Tshwane, a comprehensive approach that integrates transport planning and various modes of transport is needed. The guidelines proposed in Fig. 2 are by no means exhaustive but are an indication of potential approaches that may be used by the City of Tshwane to reduce the negative impacts of transportation.

Walking is the oldest basic clean mode of transport that promotes health and fitness. In this category, it is recommended to improve pedestrian infrastructure and facilities so as to improve safety of pedestrian. End-of-trip facilities such as bathrooms, locker rooms within workplaces have the potential to promote walking among the employed population in the City of Tshwane. End-of-trip facilities enhance the convenience, safety and attractiveness of sustainable transport modes. Walking can also be promoted through awareness campaigns.

Cycling is regarded as a friendly mode of transport to the environment that also promotes health and fitness [28], [29]. In addition, cycling acts as a feeder mode for other public transport modes such as buses and trains. A considerable number of commuters initiate and finish their journeys with bicycle in cities such as Guangzhou and Copenhagen [30]. Based on the findings of this study, the main concerns about cycling in the City of Tshwane were safety and security. In the City of Tshwane, safety and security of cyclists may be improved through infrastructure and facilities for example, provision of separate cycling lanes, secure bicycle parking, clear rules and signage that protects cyclists.

In order to promote the use of public transport in the City of Tshwane is recommended to improve service quality and integration of sustainable transport modes. Mere provision of public transport not good enough to draw commuters from their private cars [5]. High quality public transport that is well connected to other sustainable transport modes is perceived as attractive [13]. Hence it has the potential to shift private cars users to public transport. Reliability of public transport is highly regarded as attractive to the commuters [31]. It could be important for the City of Tshwane to consider provision of additional public transport routes to increase the coverage of public transport service network to less populated areas. 
Guideline 4 in Fig. 2 may be successful only if alternative sustainable transport modes are effective and efficient. In the City of Tshwane higher car usage may be reduced by implementation of car restriction policies and parking management. Car restriction policies may be applied in such a way that it become difficult to own and drive private cars.

\section{CONCLUSION}

The frequent use of private cars in the city has significant impact to both the environment and human life. In South Africa, especially City of Tshwane, there is an increase use of private cars and the existing urban transport infrastructure is insufficient to cater for the existing and future demand for transport. Hence, there is a need to shift from private car to sustainable transport modes such as cycling, walking and public transport.

The major finding of the study was that private car is the most frequently used mode of transport. The results of the study revealed that the major concerns about sustainable transport modes are safety and security, reliability and convenience. In order to address the main objective of the study as well as to promote sustainable transportation in the City of Tshwane, transport initiatives that promote use of sustainable transport modes are recommended in Fig. 2. The guidelines proposed are by no means exhaustive but are an indication of potential approaches that may be used in the City of Tshwane to reduce the negative impacts of transportation. The guidelines for sustainable urban transport attempts to give reference to the policy makers and local decision makers.Awareness of sustainable transport options in the various regions of the City of can also contribute to the needs of the current generation and met without compromising the needs of the future generation. As a way of increasing cycling in the city, future research could investigate the feasibility of public bike rental systems in the City of Tshwane.

\section{REFERENCES}

[1] Robert, K-H., Boren, S., Ny, H. \& Broman, G., A strategic approach to sustainable transport system development Part 1: Attempting a generic community planning process model. Journal of Cleaner Production, 140, pp. 53-61, 2017. DOI: 10.1016/j.jclepro.2016.02.054.

[2] Rizzi, L.I. \& Maza, C., The external costs of private versus public road transport in the metropolitan area of Santiago, Chile. Transportation Research Part A: Policy and Practice, 98, pp. 123-149, 2017. DOI: 10.1016/j.tra.2017.02.002.

[3] International Energy Agency (IEA), $\mathrm{CO}_{2}$ emissions from fuel combustion highlights 2015. International Energy Agency, Paris, 2015.

[4] Zheng, L. \& Hensher, D.A., Congestion charging and car use: A review of stated preference and opinion studies and market monitoring evidence. Transport Policy, 20, pp. 47, 2017.

[5] Luke, R., Car ownership perceptions and intentions amongst South African students. Journal of Transport Geography, 66, pp. 135-143, 2018.

DOI: 10.1016/j.jtrangeo.2017.11.010.

[6] Sitanyiova, D. \& Masarovicova, S., Development status of status of sustainable urban mobility plans in European Union new member states. International Journal of Transportation, Development and Integration, 1(1), pp. 16-27, 2017. DOI: 10.2495/tdi-v1-n1-16-27.

[7] Andong, R.F. \& Sajor, E., Urban sprawl, public transport and increasing $\mathrm{CO}_{2}$ emissions: the case of Metro Manila, Philippines. Environment, Development and Sustainability, 19(1), pp. 99-123, 2017. DOI: 10.1007/s10668-015-9729-8. 
[8] Statistics South Africa (Stats SA), 2014, The National Household Travel Survey in South Africa (NHTS). Online. www.statssa.gov.za. Accessed on: 10 Feb. 2017.

[9] Verma, M, Rahul, T.M, Reddy, V.P. \& Verma, A., The factors influencing bicycling in the Bangalore city. Transportation Research Part A: Policy and Practice, 89, pp. 29-40, 2016. DOI: 10.1016/j.tra.2016.04.006.

[10] Khoo, H.L. \& Ong, G.P., Understanding sustainable transport acceptance behaviour: A case study of Klang Valley, Malaysia. International Journal of Sustainable Transportation, 9(3) pp. 227-239, 2015. DOI: 10.1080/15568318.2012.757401.

[11] Puhe, M. \& Schippl, J., User perceptions and attitudes on sustainable urban transport among young adults: Findings from Copenhagen, Budapest and Karlsruhe. Journal of Environmental Policy \& Planning, 16(3), pp. 337-357, 2014.

DOI: $10.1080 / 1523908 x .2014 .886503$.

[12] Xia, T., Zhang, Y., Braunack-Mayer, A. \& Crabb, S., Public attitudes towards encouraging sustainable transportation: An Australian case study. International Journal of Sustainable Transportation, 11(8), pp. 593-601, 2017.

DOI: 10.1080/15568318.2017.1287316.

[13] Malasek, J., A set of tools for making urban transport more sustainable. Transportation Research Procedia, 14, pp. 876-885, 2016. DOI: 10.1016/j.trpro.2016.05.059.

[14] Buehler, R., Pucher, J., Gerike, R. \& Gotschi, T., Reducing car dependence in the heart of Europe: Lessons from Germany, Austria, and Swirtzerland. Transport Reviews, 37(1), pp. 4-28, 2017a. DOI: 10.1080/01441647.2016.1177799.

[15] Buehler, R., Pucher, J. \& Altshuler, A., Vienna's path to sustainable transport. International Journal of Sustainable Transport. 11(4), pp. 257-271, 2017b. DOI: 10.1080/15568318.2016.1251997.

[16] Klungboonkrong, P., Jaensirisak, S. \& Satiennam, T., Potential performance of urban land use and transport strategies in reducing greenhouse gas emissions: Khon Kaen case study, Thailand. International Journal of Sustainable Transportation, 11(1), pp. 36-48, 2017. DOI: 10.1080/15568318.2015.1106249.

[17] Gossling, S., ICT and transport behaviour: A conceptual review. International Journal of Sustainable Transportation, 12(3), pp. 153-164, 2018. DOI: 10.1080/15568318.2017.1338318.

[18] Bakker, S., Zuidgest, M., Coninck, H. \& Huizenga, C., Transport, development and climate change mitigation: Towards an integrated approach. Transport Reviews, 34(3), pp. 335-355, 2014. DOI: 10.1080/01441647.2014.903531.

[19] Department of Transport (DoT), Draft national non-motorised transport policy. Online. www.dot.gov.za 2008. Accessed on: 10 Feb. 2018).

[20] Statistics South Africa (Stats SA), Community survey 2016. www.statssa.gov.za. Accessed on: 5 Jun. 2017.

[21] City of Tshwane, Maps and GIS, 2016. www.tshwane.gov.za. Accessed on: 20 Feb. 2017.

[22] Welman, C., Kruger, F. \& Mitchell, B., Research Methods, 4th ed., Oxford Southern Africa, 2013.

[23] Zikmund, W.G. \& Babin, B.J., Essentials of Marketing Research, 4th ed., SouthWestern Cengage Learning, 2010.

[24] Liu, Q., Liddawi, S. \& Han, Y., Key Factors of Public Attitude Towards Sustainable Transport Policies: A Case Study in Four Cities in Sweden, Blekinge Institute of Technology Karlskrona: Sweden, 2015. 
[25] Gatersleben, B. \& Appleton, K., Contemplating cycling to work: Attitudes and perceptions in different stages of change. Transportation Research Part A: Policy and Practice, 41(4), pp. 302-312, 2007. DOI: 10.1016/j.tra.2006.09.002.

[26] Fishman, E., Washington, S., Haworth, N. \& Watson, A., Factors influencing bike share membership: Analysis of Melbourne and Brisbane. Transportation Research Part A: Policy and Practice, 71, pp. 17-30, 2015. DOI: 10.1016/j.tra.2014.10.021.

[27] Sun, Y., Mobasheri, A., Hu, X. \& Wang, W., Investigating impacts of environmental factors on the cycling behaviour of bicycle-sharing users. Sustainability, 9(6), p. 1060, 2017. DOI: $10.3390 / \mathrm{su} 9061060$.

[28] Hopkins, D. \& Mandic, S., Perceptions of cycling among high school students and their parents. International Journal of Sustainable Transportation, 11(5), pp. 342-356, 2017. DOI: $10.1080 / 15568318.2016 .1253803$.

[29] Li, Z., Wang, W., Yang, C. \& Ragland, D.R., Bicycle commuting market analysis using attitudinal market segmentation approach. Transportation Research Part A: Policy and Practice, 47, pp. 56-68, 2017. DOI: 10.1016/j.tra.2012.10.017.

[30] Zhang, R., Fujimori, S., Dai, H. \& Hanaoka, T., Contribution of transport sector to climate change mitigation: Insights from a global passenger transport model coupled with a computable general equilibrium model. Applied Energy, 211, pp. 76-88, 2018. DOI: 10.1016/j.apenergy.2017.10.103.

[31] Vilakazi, A. \& Govender, K.K., Exploring public bus service quality in South Africa: A structural equation modelling approach. Journal of Transport and Supply Chain Management, 8(1), pp. 1-10, 2014. DOI: 10.4102/jtscm.v8i1.127. 